\title{
The Blood Lead, Blood Pressure Connection: An Evaluation of Apparently Healthy Lead Exposed Workers in Nigeria
}

\author{
Datonye Dennis Alasia* (D), Alagoma Murtala Iyagba (1) \\ Department of Internal Medicine, College of Health Sciences, University of Port Harcourt, \\ Port Harcourt, Nigeria \\ Email: *datonye.alasia@uniport.edu.ng
}

How to cite this paper: Alasia, D.D. and Iyagba, A.M. (2019) The Blood Lead, Blood Pressure Connection: An Evaluation of Apparently Healthy Lead Exposed Workers in Nigeria. Occupational Diseases and Environmental Medicine, 7, 75-90.

https://doi.org/10.4236/odem.2019.73007

Received: June 27, 2019

Accepted: August 11, 2019

Published: August 14, 2019

Copyright $\odot 2019$ by author(s) and Scientific Research Publishing Inc. This work is licensed under the Creative Commons Attribution International License (CC BY 4.0).

http://creativecommons.org/licenses/by/4.0/

\begin{abstract}
Objective: There is a paucity of evidence on the lead exposure and blood pressure association in Nigeria where lead exposure is still prevalent and poorly regulated. The objective of this study was to evaluate the association between lead exposure using blood lead level and blood pressure in Port Harcourt Nigeria. Methodology: A prospective cross sectional comparative study of adult subjects with occupational lead exposure and controls, performed in Port Harcourt, South-south Nigeria. Blood lead measured by atomic absorption spectrophotometry was used as the biomarker of lead exposure while systolic and diastolic blood pressures and other relevant variables were measured and analysed. Results: The mean systolic blood pressure was significantly higher in lead exposed subjects 118.49 (14.67) $\mathrm{mmHg}$ compared to controls $113.62(11.31) \mathrm{mmHg}(\mathrm{p}=0.008)$. No difference was observed in the mean diastolic blood pressure. A higher proportion of subjects had systolic and diastolic pressure $>140 \mathrm{mmHg}$ and $>90 \mathrm{mmHg}$ compared to controls $9.47 \%$ vs. $1.25 \%$ and $10.51 \%$ vs. $2.54 \%$, with $(\mathrm{p}=0.016), \mathrm{OR}=8.27<$ $1.14<\mathrm{OR}<169.09>$, $\mathrm{RR}=1.38<1.21<\mathrm{RR}<1.58>$ and $(\mathrm{p}=0.028), \mathrm{OR}=$ $4.59<1.00<\mathrm{OR}<29.15>\mathrm{RR}=1.33<1.13<\mathrm{RR}<1.55>$ respectively. There was no significant statistical correlation between blood lead and blood pressure. Conclusion: The results of this study indicate a significant systolic blood pressure elevation and prevalence of hypertension among lead exposed workers in Port Harcourt Nigeria. Lager longitudinal research is needed to evaluate lead exposure and elevated blood pressure association in Nigeria. The findings call for better regulation of occupational lead exposure in Nigeria.
\end{abstract}

\section{Keywords}

Blood Pressure, Lead Exposure, Nigeria 


\section{Introduction}

Occupational and environmental lead exposure has been associated with blood pressure elevation [1]. Lead induced hypertension has been shown to occur even in the absence of symptomatic lead intoxication and even before the onset of clinically apparent renal impairment [2] [3] [4]. Several epidemiologic studies [5] [6] [7] [8] [9] have shown that relatively low level of lead exposure is associated with a significant increase in blood pressure. This epidemiological association of lead exposure and elevated blood pressure has been shown to contribute largely to the disease burden attributable to lead, as a result of its associated cardiovascular risk [10] [11]. Similarly lead toxicity has also been associated with an increase in the all cause circulatory and cardiovascular mortality in the United States of America as shown in the Second National Health and Nutrition Assessment Survey (NHANES II) [12] [13]. The Analysis of the NHANES II in the USA showed that blood lead levels (BLL) where significantly higher in groups with diastolic blood pressure above $90 \mathrm{mmHg}$. Blood lead increase from 0.68 to $1.45 \mathrm{umol} / \mathrm{l}(14-30 \mathrm{ug} / \mathrm{dl})$ resulted in an increase of $7 \mathrm{mmHg}$ in mean systolic blood pressure and $3 \mathrm{mmHg}$ in mean diastolic blood pressure [14]. A cross sectional and longitudinal study from Canada [15] also established the link between lead exposure and diastolic blood pressure. The NHANES III survey also showed that lead level remains significantly and positively related to elevated BP and hypertension among blacks, who had higher blood lead concentrations compared with whites [16]. The positive correlation between increasing lead exposure biomarkers and hypertension has also been demonstrated in many studies globally as shown in reports from the NHANES II survey [17] [18] and other studies in Spain [19], China [20], Kenya [21], Nigeria [22] Japan [23] and Saudi Arabia [24].

In spite of the association of lead exposure and hypertension, there are divergent results from other studies [25]-[31] which indicate a negative or weak association on the relationship between BLL and hypertension. However the general consensus is that the marginal elevation of blood pressure induced by even low level lead exposure evaluated through biomarkers like bone and blood lead remains significant [32] [33] [34]. The significance of the above association is magnified by the high population risk from lead exposure and the relationship between lead related blood pressure elevation, cardiovascular morbidity and mortality and renal function impairment. [10] [12] [13] [14] [16] [34] [35] [36].

Therefore in a country like Nigeria where lead exposure and toxicity risk remain high as evidenced by studies across the country [37] [38]; the recent acute lead toxicity resulting in the death of many children [39] [40] and the low knowledge and awareness of lead exposure [41], it is justified to evaluate the relationship of lead exposure and it multisystem effects including hypertension.

The objective of this study was to evaluate the association between lead exposure using blood lead level (BLL) as the marker of exposure and blood pressure among apparently healthy lead exposed workers in Port Harcourt Nigeria. 


\section{Methodology}

This was a comparative cross sectional study among adults with occupational risk for lead exposure in Port Harcourt an urban city in South Nigeria. The study population consisted of male and female adults between the ages of 18 - 60 years residing in Port Harcourt, Nigeria. Consenting adults within the study age range working in occupations with risk for lead exposure for at least 2 years were recruited. The subjects were selected by stratified sampling on an occupational basis, from the following occupational groups as follows: Welding/Metal works 42 subjects, Paint/Pigment workers 38 subjects, Radiator repairers 37 subjects, Battery workers 37 subjects and Petrol workers 36 subjects. The study subjects were compared with 80 age matched controls with limited occupational risk for lead exposure. Ethical approval was obtained from the University of Port Harcourt Teaching Hospital, ethics and research committee and all subjects and controls gave informed consent before participation. Persons with established Hypertension, Diabetes Mellitus, evidence of previous renal disease, Habitual use of Mercury and hydroquinone (Nephrotoxicants) containing cosmetics and significant Analgesic abuse defined by a cumulative life time use of over 20points were excluded [42]. A clinical evaluation including socio-demographic assessment, clinical and occupational history was done. Blood pressure (BP) measurements and BMI were obtained in accordance with WHO STEPs instrument guide for physical measurement [43]. The blood lead level (BLL) was measured in subjects as a marker of lead exposure using venous blood collected with sealed plastic containers without anticoagulant and analyzed by atomic absorption spectrometry [44].

\section{Statistical Analysis}

Data were analysed with SPSS Version 22. Mean, standard deviation, Median and Range were calculated for quantitative data. With results presented as Mean, standard error of mean (SEM) and Standard deviation (SD). Tests of significance were calculated using the student $\mathrm{t}$-test for independent samples, the $\mathrm{F}$ test and Analysis of variance (ANOVA). Qualitative and categorical data were compared using the chi-square tests. A p value of $<0.05$ was set as statistically significant. Pearson bivariate correlation analysis and regression analysis was used to determine the relationship between BLLs, blood pressure and other study variables with $\mathrm{p}$ values of $<0.05$ considered significant as appropriate.

\section{Results}

\subsection{Demographics of Subjects}

The demographic summary of study population is as displayed in Table 1 and Table 2. The mean age of lead exposed subjects was $34.78 \pm 0.728$ years (yrs.) compared to controls with $35.95 \pm 1.128$ years, $\mathrm{p}$ (0.385) (See Table 3 ).

The mean age of the study subjects in the various occupational groups is as stated: welding and metal workers $31.59 \pm 9.32$ yrs., Paint and Pigment $35.13 \pm$ 
Table 1. Demographic details of all study participants.

\begin{tabular}{|c|c|c|c|c|}
\hline Variables & $\begin{array}{l}\text { Frequency } \\
\text { Distribution }\end{array}$ & $\begin{array}{l}\text { Frequency } \\
\mathrm{N}(\%)\end{array}$ & Range & Mean \pm SD \\
\hline \multirow[t]{4}{*}{ Age (Years) } & $18-30$ & $104(38.5 \%)$ & $18-58$ & $35.13 \pm 10.06$ \\
\hline & $31-40$ & $73(27.0 \%)$ & & \\
\hline & $41-50$ & $61(22.6 \%)$ & & \\
\hline & $51-60$ & $32(11.9 \%)$ & & \\
\hline \multirow[t]{2}{*}{ Sex } & Male & $209(77.4 \%)$ & & \\
\hline & Female & $61(22.6 \%)$ & & \\
\hline DOC (Years) & & & $1-48$ & $10.77 \pm 8.90$ \\
\hline \multirow[t]{2}{*}{$\begin{array}{l}\text { Smoking/Intake } \\
\text { (Pack years) }\end{array}$} & Smokers & $12(4.4 \%)$ & $0-15$ & $0.42 \pm 2.20$ \\
\hline & Non Smokers & $258(95.6 \%)$ & & \\
\hline \multirow[t]{2}{*}{$\begin{array}{l}\text { Alcohol intake } \\
\text { (grams/week) }\end{array}$} & Take alcohol & $73(27 \%)$ & $0-216$ & $17.20 \pm 37.52$ \\
\hline & Do not take alcohol & $197(73 \%)$ & & \\
\hline \multirow[t]{6}{*}{ BMI $\left(\mathrm{Kg} / \mathrm{m}^{2}\right)$} & $<18.5$ & $5(1.85 \%)$ & $16.94-47.96$ & $25.28 \pm 4.16$ \\
\hline & $18.5-24.9$ & $136(50.37 \%)$ & & \\
\hline & $25-29.9$ & $98(36.3 \%)$ & & \\
\hline & $30-34.9$ & $26(9.63 \%)$ & & \\
\hline & $35-39.9$ & $3(1.11 \%)$ & & \\
\hline & $>40$ & $2(0.74 \%)$ & & \\
\hline
\end{tabular}

Table 2. Comparison of demographic variables between subject and controls.

\begin{tabular}{|c|c|c|c|c|c|}
\hline \multirow[b]{2}{*}{ Variables } & \multirow{2}{*}{$\begin{array}{l}\text { Frequency } \\
\text { Distribution }\end{array}$} & \multicolumn{2}{|c|}{ Subjects } & \multicolumn{2}{|c|}{ Controls } \\
\hline & & $\begin{array}{c}\text { Frequency } \\
\mathrm{N}(\%)\end{array}$ & Range & $\begin{array}{c}\text { Frequency } \\
\mathrm{N}(\%)\end{array}$ & Range \\
\hline \multirow[t]{4}{*}{ Age (Years) } & $18-30$ & $78(41.6 \%)$ & $18-58$ & $26(32.5 \%)$ & $19-58$ \\
\hline & $31-40$ & 49 (25.8\%) & & $24(30.0 \%)$ & \\
\hline & $41-50$ & $42(22.1 \%)$ & & $19(23.8 \%)$ & \\
\hline & $51-60$ & $21(11.1 \%)$ & & $11(13.7 \%)$ & \\
\hline \multirow[t]{2}{*}{ Sex } & Male & $151(79.5 \%)$ & & $58(72.5 \%)$ & \\
\hline & Female & $39(20.5 \%)$ & & $22(27.5 \%)$ & \\
\hline DOC (Years) & & & $2-48$ & & $2-30$ \\
\hline \multirow[t]{2}{*}{$\begin{array}{c}\text { Smoking/Intake } \\
\text { (Pack years) }\end{array}$} & Smokers & $9(4.7 \%)$ & $0-15$ & $3(3.7 \%)$ & $0-10$ \\
\hline & Non Smokers & $181(95.3 \%)$ & & 77 (96.3\%) & \\
\hline
\end{tabular}




\begin{tabular}{|c|c|c|c|c|c|}
\hline \multicolumn{6}{|l|}{ Continued } \\
\hline $\begin{array}{l}\text { Alcohol intake } \\
\text { (grams/week) }\end{array}$ & Take alcohol & $53(27.9 \%)$ & $0-216$ & $20(25 \%)$ & $0-126$ \\
\hline \multirow{7}{*}{$\mathrm{BMI}\left(\mathrm{Kg} / \mathrm{m}^{2}\right)$} & $\begin{array}{c}\text { Do not } \\
\text { take alcohol }\end{array}$ & $137(72.1 \%)$ & & $60(75 \%)$ & \\
\hline & $<18.5$ & $4(2.1 \%)$ & $16.94-40.65$ & $1(1.3 \%)$ & $18.30-47.96$ \\
\hline & $18.5-24.9$ & $97(51.1 \%)$ & & $39(48.8 \%)$ & \\
\hline & $25-29.9$ & $74(38.9 \%)$ & & $24(30.0 \%)$ & \\
\hline & $30-34.9$ & $13(6.8 \%)$ & & $13(16.3 \%)$ & \\
\hline & $35-39.9$ & $1(0.5 \%)$ & & $2(2.5 \%)$ & \\
\hline & $>40$ & $1(0.5 \%)$ & & $1(1.3 \%)$ & \\
\hline
\end{tabular}

Table 3. Comparison of study variables mean in subjects and controls.

\begin{tabular}{cccccc}
\hline & Study groups & $\mathrm{N}$ & Mean & Std. Error Mean & P value \\
\hline \multirow{2}{*}{ age in years } & Subjects & 190 & 34.78 & 0.73 & 0.385 \\
& Controls & 80 & 35.95 & 1.13 & \\
duration of & Subjects & 190 & 11.92 & 0.67 & 0.001 \\
occupation (years) & Controls & 80 & 8.04 & 0.82 & \\
body mass index (kg/m $\left.{ }^{2}\right)$ & Subjects & 190 & 24.92 & 0.26 & 0.028 \\
$\begin{array}{c}\text { mean systolic blood } \\
\text { pressure (mmHg) }\end{array}$ & controls & 80 & 26.14 & 0.571 & \\
mean diastolic & controls & 80 & 113.62 & 1.26 & 0.008 \\
blood pressure (mmHg) & subjects & 190 & 74.67 & 0.79 & \\
controls & 80 & 73.24 & 0.82 & 0.285 \\
blood lead levels (ug/dl) & subjects & 190 & 50.38 & 1.78 & \\
& controls & 80 & 40.48 & 2.83 & 0.003 \\
\hline
\end{tabular}

10.65 yrs., Radiator Mechanics $34.91 \pm 8.65$ yrs., Battery worker $=36.97 \pm 10.06$ yrs., Petrol attendants $35.75 \pm 11.10$ yrs. There was no significant difference in the mean age between and within the group $\mathrm{p}=0.172$ (See Table 4).

The study population comprised of $209(77.4 \%)$ males and $61(22.6 \%)$ females, with a male to female ratio of 3.4:1. No significant difference was observed in the proportion of males and females in both groups, $\mathrm{p}=0.21$ (See Table 1). The mean BMI in the study subjects was $24.92 \pm 0.264 \mathrm{~kg} / \mathrm{m}^{2}$ with a range of $(16.94-40.65) \mathrm{Kg} / \mathrm{m}^{2}$ (see Table 2 and Table 3 ) while the mean in the controls was $26.13 \pm 0.571 \mathrm{Kg} / \mathrm{m}^{2}$ with a range of $(18.30-47.96) \mathrm{Kg} / \mathrm{m}^{2}$ (See Table 2 and Table 3). A significant difference was observed between the means, with a $\mathrm{p}$ $=0.028$ (See Table 3$)$.

The mean duration of occupation in the study subjects was $11.91 \pm 0.672 \mathrm{yrs}$ with a range of $(2-48)$ yrs, while the value in controls was $8.03 \pm 0.818$ range of (2 - 30) yrs. A significant difference was observed between the means, with a $\mathrm{p}=$ 0.001 (See Table 2 and Table 3). 
Table 4. Comparison of mean age in the different occupational groups of study subjects.

\begin{tabular}{ccccc}
\hline Occupational Group & N & Mean Age (Years) & SD & P value \\
\hline Welding and metal & 42 & 31.59 & 9.32 & \\
Paint and pigment & 38 & 35.13 & 10.65 & \\
Radiator and auto mechanic & 37 & 34.91 & 8.65 & 0.172 \\
Battery worker & 37 & 36.97 & 10.06 & \\
Petrol worker & 36 & 35.75 & 11.10 & \\
\hline
\end{tabular}

$\mathrm{SD}=$ Standard Deviation

\subsection{Blood Lead Pattern}

There was a significant difference in the mean blood lead levels of subjects compared controls $50.37 \pm 1.784 \mathrm{ug} / \mathrm{dl}$ vs. $41.40 \pm 2.832 \mathrm{ug} / \mathrm{dl}$ ( $\mathrm{p}=0.008)$, (See Table 3).

Subjects in the welding/metal work group had the highest mean BLL of 54.25 (26.94) ug/dl, trailed by battery workers 52.59 (28.05) ug/dl, paint/pigment workers $49.36(20.73) \mathrm{ug} / \mathrm{dl}$, radiator repairers 48.89 (24.13) ug/dl and petrol workers 46.16 (22.46) ug/dl respectively. There was no significant difference between the group means of the various occupational groups of the subjects (See Table 5).

The distribution of BLL by blood lead groups in both subjects and controls shows that $92.1 \%$ of subjects and $72.6 \%$ of controls had BLL above level $2>20$ $\mathrm{ug} / \mathrm{dl}$, with a significant difference in the proportions, expressed by $\mathrm{p}=0.000$ and $\mathrm{RR}=1.85<1.25<\mathrm{RR}<2.76>$ (See Table 6).

\subsection{Blood Pressure Pattern}

The mean systolic blood pressure (SBP) in study subjects was $118.49 \pm 1.065$ mmHg compared to $113.62 \pm 1.265 \mathrm{mmHg}$ in controls with a significant difference observed, expressed by $\mathrm{p}=0.008$ (See Table 3 ). There was no significant difference in mean diastolic blood pressure (DBP) in study subjects $74.64 \pm$ $0.7967 \mathrm{mmHg}$ compared to $73.10 \pm 0.8173 \mathrm{mmHg}, \mathrm{p}=0.285$ (See Table 3).

The mean values of systolic and diastolic blood pressure of the subjects in various occupational groupings did not vary significantly with $p$ values of 0.055 and 0.760 respectively (See Table 7).

A significantly higher proportion of subjects $9.47 \%$ had SBP $\geq 140 \mathrm{mmHg}$ compared with $1.25 \%$ in controls, $\mathrm{p}=0.016$ with a relative risk $(\mathrm{RR})=1.38<$ $1.21<\mathrm{RR}<1.58>$. A significantly higher proportion of subjects $9.5 \%$ had $\mathrm{DBP} \geq$ $90 \mathrm{mmHg}$ compared to $2.5 \%$ of controls, $\mathrm{p}=0.028$ and a $\mathrm{RR}=1.33<1.13<\mathrm{RR}$ $<1.55>$ (See Table 6).

\subsection{Blood Lead and Blood Pressure Association}

There was no significant direct correlation between BLL and BP on Bivariate correlation and single and multiple linear regression analysis. 
Table 5. Blood lead levels by occupational groups of subjects.

\begin{tabular}{cccccc}
\hline Variable & Occupational Group & N & Mean & SD & P Value \\
\hline Blood lead levels & Welding and metal & 42 & 54.25 & 26.94 & 20.73 \\
Paint and pigment & 38 & 49.36 & 48.89 & 24.13 & 28.05 \\
Radiator and auto mechanic & 37 & 52.59 & 46.16 & 22.46 & NS \\
Battery worker & Petrol worker & 36 & 50.37 & 24.58 \\
\hline
\end{tabular}

NS $=$ Not Significant, SD $=$ Standard Deviation

Table 6. Comparative frequency of blood lead and blood pressure elevation in study population.

\begin{tabular}{ccccccc}
\hline Variable & $\mathrm{N}(190)$ & $\%$ of $\mathrm{n}$ & $\mathrm{n}(80)$ & $\%$ of $\mathrm{n}$ & P value & RR (Relative Risk) \\
\hline Blood Lead $>20 \mathrm{ug} / \mathrm{dl}$ & 175 & $92.1 \%$ & 58 & $72.5 \%$ & 0.000 & $1.85<1.25<\mathrm{RR}<2.76>$ \\
Systolic Blood Pressure $\geq 140 \mathrm{mmHg}$ & 18 & $9.47 \%$ & 1 & $1.25 \%$ & 0.016 & $1.38<1.21<\mathrm{RR}<1.58>$ \\
Diastolic Blood Pressure $\geq 90 \mathrm{mmHg}$ & 20 & $9.5 \%$ & 2 & $2.5 \%$ & 0.028 & $1.33<1.13<\mathrm{RR}<1.55$ \\
\hline
\end{tabular}

Table 7. Blood pressure level in various occupational groups of subjects.

\begin{tabular}{|c|c|c|c|c|c|c|c|c|c|c|c|c|}
\hline \multirow[b]{2}{*}{ Occupational Group } & \multicolumn{3}{|c|}{ Systolic BP (mmHg) } & \multicolumn{2}{|c|}{$95 \%$ CI for mean } & \multirow{2}{*}{$\begin{array}{c}\text { Combined } \\
\mathrm{P} \text { value }\end{array}$} & \multicolumn{3}{|c|}{ Diastolic BP (mmHg) } & \multicolumn{2}{|c|}{$95 \%$ CI for mean } & \multirow{2}{*}{$\begin{array}{c}\text { Combinec } \\
\text { P value }\end{array}$} \\
\hline & $\mathrm{N}$ & Mean & SEM & LB & UB & & $\mathrm{N}$ & Mean & SEM & LB & UB & \\
\hline Welding metal & 42 & 123.43 & 1.89 & 119.61 & 127.25 & & 42 & 73.32 & 1.68 & 66.92 & 76.72 & \\
\hline Paint pigment & 38 & 119.11 & 2.05 & 114.95 & 123.26 & 0.055 & 38 & 73.95 & 2.26 & 69.37 & 78.53 & 0.760 \\
\hline Radiator automechanic & 37 & 116.35 & 2.51 & 111.27 & 121.435 & & 37 & 75.99 & 1.63 & 72.68 & 79.29 & \\
\hline Battery worker & 37 & 118.86 & 2.75 & 113.29 & 124.437 & & 37 & 75.97 & 1.37 & 73.22 & 78.72 & \\
\hline Petrol workers & 36 & 11.88 & 2.55 & 108.71 & 119.069 & & 36 & 74.32 & 1.89 & 70.46 & 78.16 & \\
\hline
\end{tabular}

Legend: SEM-Standard Error of Mean, CI-Confidence Interval, LB - Lower bound, UB-Upper bound, N-Number.

In linear regression modelling DOC was significantly and positively associated with SBP $\left[\mathrm{r}=0.256, \mathrm{r}^{2}=0.065, \mathrm{p}=0.000\right]$ (Figure 1) and DBP $\left[\mathrm{r}=0.137, \mathrm{r}^{2}=\right.$ $0.019, \mathrm{p}=0.025]$ (Figure 2). Other significant correlations were SBP and DBP [ $\mathrm{r}$ $=0.138, \mathrm{p}=0.024]$ and SBP and BMI $[\mathrm{r}=0.184, \mathrm{p}=0.002]$.

With multiple linear regression analysis model DOC was also independently significantly and positively correlated with SBP $\left[r=0.532, r^{2}=0.238, p=0.000\right]$. The significant predictors of this association in this regression model were increasing age $\mathrm{p}=0.000, \mathrm{BMI} \mathrm{p}=0.031$ and alcohol consumption $\mathrm{p}=0.003$.

\section{Discussion}

It is noted that most of the studies on lead exposure and blood pressure relationship have been done in developed countries. There is consequently a paucity of studies evaluating the role and contribution of lead exposure on elevated blood pressure and hypertension in countries like Nigeria, where lead exposure is considered to be prevalent and unregulated [37] [38] [39] [40] [41] and 


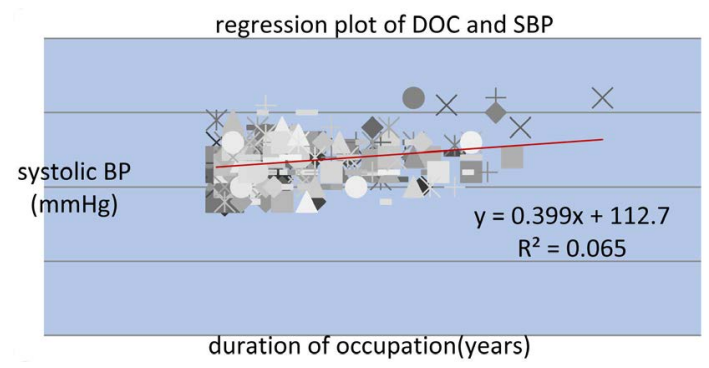

Figure 1. Correlation regression plot showing significant association between duration of occupation and systolic blood pressure.

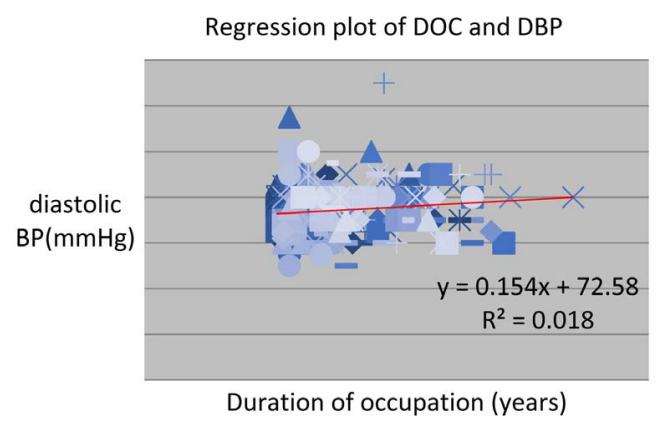

Figure 2. Correlation regression plot showing significant association between duration of occupation and diastolic blood pressure.

hypertension is common [45] [46].

This study which evaluated the relationship of blood lead and blood pressure among lead exposed workers established a significantly higher degree of lead exposure in the study subjects compared to controls as demonstrated by significantly higher mean BLL in study subjects compared to controls $50.3 \pm 24.5 \mathrm{ug} / \mathrm{dl}$ vs. $41.40 \pm 26.85 \mathrm{ug} / \mathrm{dl}$.

This finding is consistent with reports from other Nigerian studies reporting higher mean BLL in occupationally exposed populations compared to controls of $56.3 \pm 0.95 \mathrm{ug} / \mathrm{dl}$ vs $30.47 \pm 1.4 \mathrm{ug} / \mathrm{dl}$ [47], $48.09 \pm 9.08 \mathrm{ug} / \mathrm{dl}$ vs $33.65 \pm 10.09$ $\mathrm{ug} / \mathrm{dl}$ [48] and $46.0 \pm 0.19 \mathrm{ug} / \mathrm{dl}$ vs $31.0 \pm 0.10 \mathrm{ug} / \mathrm{dl}$ [38] respectively. Similar reports have also been documented from other countries outside Africa as shown by Jung et al. [49] who reported the following mean BLL of $74.6 \pm 7.8$ $\mu \mathrm{g} / \mathrm{dl}, 46.5 \pm 5.9 \mu \mathrm{g} / \mathrm{dl}$ and $24.3 \pm 2.7 \mu \mathrm{g} / \mathrm{dl}$ respectively in the highly exposed, moderately exposed and slightly exposed Korean lead workers compared to $7.9 \pm$ $1.4 \mathrm{ug} / \mathrm{dl}$ in the control group while Sadeghniiat-Haghighi et al. in a study of Iranian workers reported a mean BLL of $44.04 \pm 16.05 \mathrm{ug} / \mathrm{dl}$ with a range of 15.6 - $85.6 \mathrm{ug} / \mathrm{dl}[50]$.

It is also known that lead exposure and BLL above $20 \mathrm{ug} / \mathrm{dl}$ are associated with a variety of multisystem effects which include hypertension, cardiovascular risk and renal disease. The results of this study showed a significantly higher prevalence of BLL above level $2>20 \mathrm{ug} / \mathrm{dl}$ in subjects as $92.1 \%$ of subjects and $72.6 \%$ of controls had blood lead above level $2>20 \mathrm{ug} / \mathrm{dl}$. Compatible results have also been documented in Nigeria by Adeniyi and Anetor [37] who documented a 
prevalence of $95.3 \%$ of exposed workers and $82 \%$ of controls with BLL above 40 ug/dl.

With the established finding of higher levels and prevalence of lead exposure using BLL as the marker in the study we then examined the relationship between blood lead and blood pressure and the predictors of blood pressure elevation in study population. The mean systolic blood pressure was significantly higher in the study subjects compared to controls 118.49 (1.065) $\mathrm{mmHg}$ vs 113.62 (1.265) $\mathrm{mmHg}$, while there was no significant difference in the diastolic blood pressure of both groups $74.64(0.7967) \mathrm{mmHg}$ vs $73.10(0.8173)$. This study also reported a higher frequency of systolic (9.47\% vs $1.25 \%)$ and diastolic hypertension (9.5\% vs $2.5 \%$ ) in the study subject compared to controls with a significant higher relative risk.

The findings in this study are consistent with that of Pergrande et al. [50] who reported higher systolic blood pressure in lead exposed workers compared to controls and similar diastolic blood pressure in both groups. Were et al. [21] in a study of an occupational population in Kenya reported a high prevalence of hypertension as approximately $30 \%$ of workers had hypertensive range blood pressure with an average systolic and diastolic blood pressure (BP) of $134.7 \pm$ $12.7 \mathrm{mmHg}$ and $86.4 \pm 8.9 \mathrm{mmHg}$, respectively, in comparison with the findings of this study which also showed higher prevalence of Hypertension in lead exposed workers. The finding of this study of a higher risk of hypertension in workers with higher lead levels also matches the report from Han et al. [7] in an occupational exposed population study in China reporting higher rates and risk of hypertension in workers with higher levels of lead exposure; and Nomiyama et al. [23] who reported a positive association between blood lead and systolic blood and diastolic blood pressure in lead workers especially at concentrations higher than $40 \mu \mathrm{g} / \mathrm{dl}$. Other population based studies [4] [5] [6] [20] and studies among hypertensive populations [24] also report higher prevalence and risk of elevated blood pressure in relation to higher blood lead levels.

The significantly higher systolic blood pressure level and the higher prevalence of hypertension based on both systolic and diastolic blood pressure values in the hypertensive range observed in the occupational exposed subjects compared to controls indicate that lead exposed subjects have a higher likelihood of developing hypertension in this study. The probable mechanisms by which lead exposure results in elevated blood pressure include interference by lead with sodium-lithium counter cation transport system in the same direction as observed in essential hypertension [51]; in addition to the direct effects on arterial smooth muscle through its interference with calcium metabolism by increasing free intracellular calcium concentrations and inhibition of vascular smooth muscle (Na-K-ATPase) resulting in increased vascular smooth muscle tone and vascular contractility [52] [53]. Additional pathways for lead induced blood pressure elevation include increase in the vasoconstrictor endothelin-3 (ET-3) [54] and lead indirect effect through reactive oxygen species (ROS) [55] [56] which inactivate nitric oxide (NO) and cause a decrease in the vasodilator hormone endothelial 
derived growth factor (EDRF). Studies have also shown increase in plasma renin activity (PRA) [57]; effects on the renin angiotensin system (RAS) and vascular beta adrenergic and dopaminergic activity as routes through which lead results in blood pressure increase [58] [59]. The above outlined mechanisms of lead induced blood pressure elevation may therefore explain the significantly elevated systolic blood pressure in the study subjects.

Though this study found significantly higher prevalence of hypertension and higher mean systolic blood pressure in the study subjects with higher blood lead levels there was no correlations with blood lead the only biomarker of lead exposure in this study and blood pressure. Cheng et al. [8], did not find a direct correlation between blood lead and blood pressure, but reported a correlation between bone lead levels and hypertension. In conformity with the finding of this study Sadeghniiat-Haghighi et al. [30] documented a borderline non-significant association between blood lead and systolic blood pressure and no association with diastolic blood pressure though chelated lead was significantly associated with systolic blood pressure increases. In contrast to our findings positive association between blood lead and systolic and diastolic blood pressure have also been reported by many studies [6] [7] [20] [21] [22] [24]. The lack of correlation of BLL and hypertension in this study may be a function of the effectiveness of BLL a marker of lead exposure function as studies [2] [8] [9] suggest that use of long term and equilibrated lead exposure markers such as bone lead may be more reliable.

In spite of lack of evidence of correlation between blood lead and hypertension in this study; the duration of occupation (DOC) an index of the length of lead exposure correlated positively with systolic and diastolic blood pressure on bivariate correlation and linear regression. The results of the multiple linear regression analysis model in this study showed that DOC was also independently significantly and positively correlated with SBP $\left[r=0.532, r^{2}=0.238, p=0.000\right]$, however the association between DOC and DBP was not significant, $\mathrm{p}=0.215$. The results of multiple linear regression analysis model in this study showed that the significant predictors of increasing systolic blood pressure were increasing age $\mathrm{p}=0.000$, alcohol consumption $\mathrm{p}=0.003$ and BMI $\mathrm{p}=0.031$. In comparison with the results of this study the following variables of Age [6] [21], BMI [9] [22] [30] and DOC [21] have also been reported as predictors which influence blood pressure elevation associated with lead exposure by other studies. Other factors which were not identified in this study but reported in others [22] [24] [30] include cigarette smoking. The black race has also been reported as a risk for elevated blood pressure associated with lead exposure as reported in NHANES III study analysis [16] and the normative aging study [9]. This study was also done in a black population.

The relationship of blood pressure and other variables found in this study, may show that subjects with prolonged DOC with exposure to lead are more at risk of higher systolic blood pressure level compared to the controls.

The association of increasing age, alcohol consumption, BMI and blood pres- 
sure found in the study indicates the importance of these lifestyle measures in promoting hypertension as documented in existing studies [60] [61].

In conclusion, the study found an association between blood pressure elevation and lead exposure with higher systolic blood pressure and higher prevalence of hypertension. The study also found increasing BMI, Age and alcohol consumption as the significant predictors of increasing systolic blood pressure. While the study does not establish any statistical correlation between blood lead level and blood pressure the presence of higher blood pressure levels and higher prevalence of hypertension in the lead exposed subjects should be taken seriously.

Consequently larger and more longitudinal studies on the relationship between lead exposure including other lead exposure markers like bone lead and $\alpha$ amino levulonic acid dehydratase (ALAD) [44] among others should be performed to evaluate, hypertension and other systemic toxicities in this environment where lead exposure is prevalent, unregulated and awareness is low.

The reduction of environmental and occupational lead exposure needs to be prioritized and made a public health issue in Nigeria especially in subjects engaged in risk occupations. In furtherance of this goal, efforts should be intensified to improve the low awareness and regulation of lead exposure and toxicity [41]; while the expected gains from the reduction of leaded gasoline use in the country [62], should be complemented by other strategies which include the reduction of the high level of lead in paint and pigment [63] [64] and other sources of lead exposure [65]. The risk from unregulated ore mining [40] and other artisanal occupational activities which promote lead exposure ought to be reduced through tougher environmental and occupational regulation of lead exposure in order to reduce the high burden and cost of lead exposure and toxicity in Nigeria, with its established impact on cardiovascular related diseases like hypertension [66].

\section{Conflicts of Interest}

The authors declare no conflicts of interest regarding the publication of this paper.

\section{References}

[1] Harlan, W.R. (1988) The Relationship of Blood Lead Levels to Blood Pressure in the US Population. Environmental Health Perspective, 78, 9-13. https://doi.org/10.1289/ehp.88789

[2] Landrigan, P.J. (1990) Current Issues in the Epidemiology and Toxicology of Occupational Exposure to Lead. Environmental Health Perspective, 89, 61-66. https://doi.org/10.1289/ehp.908961

[3] Goyer, R.A. (1990) Lead Toxicity: From Overt to Subclinical to Subtle Health Effects. Environmental Health Perspectives, 86, 177-181.

[4] Weedeen, R.P. (1988) Bone Lead, Hypertension and Lead Nephropathy. Environmental Health Perspective, 78, 57-60. https://doi.org/10.1289/ehp.887857 
[5] Gambelunghe, A., Sallsten, G., Borné, Y., Forsgard, N., Hedblad, B., Nilsson, P., Fagerberg, B., Engström, G. and Barregard, L. (2016) Low-Level Exposure to Lead, Blood Pressure, and Hypertension in a Population-Based Cohort. Environmental Research, 149, 157-163. https://doi.org/10.1016/j.envres.2016.05.015

[6] De Almeida Lopes, A.C.B., Silbergeld, E.K., Navas-Acien, A., Zamoiski, R., da Cunha Martins Jr., A., Camargo, A.E.I., Urbano, M.R., Mesas, A.E. and Paoliello, M.M.B. (2017) Association between Blood Lead and Blood Pressure: A Population-Based Study in Brazilian Adults. Environmental Health, 16, 27-37.

https://doi.org/10.1186/s12940-017-0233-5

[7] Han, L., Wang, X., Han, R., Xu, M., Zhao, Y., Gao, Q., Shen, H. and Zhang, H. (2018) Association between Blood Lead Level and Blood Pressure: An Occupational Population-Based Study in Jiangsu Province, China. PLoS ONE, 13, e0200289. https://doi.org/10.1371/journal.pone.0200289

[8] Cheng, Y., Schwartz, J., Sparrow, D., Aro, A., Weiss, S.T. and Hu, H. (2001) Bone Lead and Blood Lead Levels in Relation to Baseline Blood Pressure and the Prospective Development of Hypertension: The Normative Aging Study. American Journal of Epidemiology, 153, 164-171. https://doi.org/10.1093/aje/153.2.164

[9] Hu, H., Aro, A., Payton, M., Korrick, S., Sparrow, D., Weiss, S.T. and Rotnitzky, A. (1996) The Relationship of Bone and Blood Lead to Hypertension. The Normative Aging Study. JAMA, 275, 1171-1176. https://doi.org/10.1001/jama.1996.03530390037031

[10] Fewtrell, L., Kautmann, R. and Pruss-Ustun, A. (2003) Lead: Assessing the Environmental Burden of Disease at National and Local Levels. WHO Environmental Burden of Disease Series No. 2, Geneva.

[11] Kopp, S.J., Barron, J.T. and Tow, J.P. (1988) Cardiovascular Actions of Lead and Relationship to Hypertension: A Review. Environmental Health, Perspective, 78, 91-99. https://doi.org/10.1289/ehp.887891

[12] Lustberg, M. and Ellen Silbergeld, E. (2002) Blood Lead Levels and Mortality. Archives of Internal Medicine, 162, 2443-2449. https://doi.org/10.1001/archinte.162.21.2443

[13] Nawrot, T.S. and Staessen, J.A. (2006) Low-Level Environmental Exposure to Lead Unmasked as Silent Killer. Circulation, 114, 1347-1349. https://doi.org/10.1161/CIRCULATIONAHA.106.650440

[14] Landis, J.R. and Flegal, K.M. (1988) A Generalized Mantel-Haenszel Analysis of the Regression of Blood Pressure on Blood Lead Using NHANES II Data. Environmental Health, Perspective, 78, 35-41. https://doi.org/10.1289/ehp.887835

[15] Neri, L.C., Hewitt, D. and Orser, B. (1988) Blood Lead and Blood Pressure: Analysis of Cross Sectional and Longitudinal Data from Canada. Environmental Health Perspectives, 78, 123-126. https://doi.org/10.1289/ehp.8878123

[16] Vupturri, S., He, J., Mutner, P., Bazzano, L.A., Whelton, P.K. and Batuman, V. (2003) Blood Lead Level Is Associated with Elevated Blood Pressure in Blacks. Hypertension, 41, 463-468. https://doi.org/10.1161/01.HYP.0000055015.39788.29

[17] Schwartz, J. (1998) The Relationship between Blood Pressure and Blood Lead in the NHANES II Survey. Environmental Health, Perspective, 78, 15-22. https://doi.org/10.1289/ehp.887815

[18] Pirkle, J.L., Schwartz, J., Landis, J.R. and Harlan, W.R. (1985) The Relationship between Blood Lead Levels and Blood Pressure and Its Cardiovascular Risk Implications. American Journal of Epidemiology, 121, 246-258.

https://doi.org/10.1093/oxfordjournals.aje.a113995 
[19] Sanchez-Fructuoso, A.I., Torralbo, A., Arroyo, M., Luque, M., Ruilope, L.M., Santos, J.L., Cruceyra, A. and Barrientos, A. (1996) Occult Lead Intoxication as a Cause of Hypertension and Renal Failure. Nephrology Dialysis Transplantation, 11, 1775-1780. https://doi.org/10.1093/ndt/11.9.1775

[20] Lu, Y., Liu, X., Deng, Q., Duan, Y., Dai, H., Li, Y., Xiao, T., Ning, X., Fan, J., Zhou, L., Li, X., Zhong, H. and Yuan, H. (2015) Continuous Lead Exposure Increases Blood Pressure But Does Not Alter Kidney Function in Adults 20-44 Years of Age in a Lead-Polluted Region of China. Kidney and Blood Pressure Research, 40, 207-214. https://doi.org/10.1159/000368496

[21] Were, F.H., Moturi, M.C., Gottesfeld, P., Wafula, G.A., Kamau, G.N. and Shiundu, P.M. (2014) Lead Exposure and Blood Pressure among Workers in Diverse Industrial Plants in Kenya. Journal of Occupational and Environmental Hygiene, 11, 706-715. https://doi.org/10.1080/15459624.2014.908258

[22] Adekunle, I.M., Osuagwu, J.N., Babalola, O.O., Arolowo, T.A. and Odukoya, O.O. (2009) Relationships between Blood Lead, Blood Pressure, Serum Cholesterol and Body Mass Index of Non-Occupationally Exposed Male Residents of Abeokuta, Nigeria. International Journal of Biological and Chemical Sciences, 3, 277-286. https://doi.org/10.4314/ijbcs.v3i2.44483

[23] Nomiyama, K., Nomiyama, H., Liu, S.-J., Tao, Y.-X. and Omae, K. (2002) Lead Induced Increase of Blood Pressure in Female Lead Workers. Occupational and Environmental Medicine, 59, 734-738. https://doi.org/10.1136/oem.59.11.734

[24] Alghasham, A.A., Meki, A.M.A. and Hisham, A.S. (2011) Association of Blood Lead Level with Elevated Blood Pressure in Hypertensive Patient. International Journal of Health Sciences, 5, 17-27.

[25] Selevan, S.G., Landrigan, P.J., Stern, F.B. and Jones, J.J. (1988) Lead and Hypertension in a Mortality Study of Lead Smelter Workers. Environmental Health, Perspective, 78, 65-66. https://doi.org/10.1289/ehp.887865

[26] Chu, N.F., Liou, S.H., Wu, T.N. and Chang, P.Y. (1999) Reappraisal of the Relation between Blood Lead Concentration and Blood Pressure among the General Population in Taiwan. Occupational and Environmental Medicine, 56, 30-33. https://doi.org/10.1136/oem.56.1.30

[27] Staessen, J.A., Roels, H. and Fagard, R. (1996) Lead Exposure and Conventional and Ambulatory Blood Pressure: A Prospective Population Study. PheeCad Investigators. JAMA, 275, 1563-1570. https://doi.org/10.1001/jama.1996.03530440043035

[28] Wu, T.N., Shen, C.Y., Ko, K.N., Guu, C.F., Gau, H.J., Lai, J.S., Chen, C.J. and Chang, P.Y. (1996) Occupational Lead Exposure and Blood Pressure. International Journal of Epidemiology, 25, 791-796. https://doi.org/10.1093/ije/25.4.791

[29] Gartside, P.S. (1988) The Relationship between Blood Lead and Blood Pressure in the NHANES II Survey: Additional Calculations. Environmental Heath Perspectives, 78, 31-34. https://doi.org/10.1289/ehp.887831

[30] Sadeghniiat-Haghighi, K., Bahaedini, L.S., Mehrdad, R., Meysami, A.P., Chavoshi, F. and Soltani, S. (2011) The Relationship between Blood Pressure and Lead Exposure in Battery Recycling Workers. Journal of Biological Sciences, 11, 454-458. https://doi.org/10.3923/jbs.2011.454.458

[31] Pocock, S.J., Shaper, A.G., Ashby, D., Delves, H.T. and Clayton, B.E. (1988) The Relationship between Blood Lead, Blood Pressure, Stroke and Heart Attacks in Middle-Aged British Men. Environmental Health, Perspective, 78, 23-30. https://doi.org/10.1289/ehp.887823

[32] Hond, E.D., Nawrot, T. and Staessen, J.A. (2003) Hypertension and Low-Level Lead 
Exposure: A Scientific Issue or a Matter of Faith? Editorial Letter. Hypertension, 42, e9. https://doi.org/10.1161/01.HYP.0000085859.22259.42

[33] Vupturri, S., Batuman, V. and He, J. (2003) Response: Hypertension and Low-Level Lead Exposure in African Americans: A Public Health Reality: Editorial Letter. Hypertension, 42, e9. https://doi.org/10.1161/01.HYP.0000085860.09080.E2

[34] Tyroler, H.A. (1988) Epidemiology of Hypertension as a Public Health Problem: An Overview as Background for Evaluation of Blood Lead-Blood Pressure Relationship. Environmental Health, Perspective, 78, 3-7. https://doi.org/10.1289/ehp.88783

[35] Moller, L. and Kristensen, T.S. (1992) Blood Lead as a Cardiovascular Risk Factor. American Journal of Epidemiology, 136, 1091-1100. https://doi.org/10.1093/oxfordjournals.aje.a116574

[36] Batuman, V., Landy, E., Maesaka, J.K. and Wedeen, R.P. (1983) Contribution of Lead to Hypertension with Renal Impairment. The New England Journal of Medicine, 309, 17-21. https://doi.org/10.1056/NEJM198307073090104

[37] Adeniyi, F.A. and Anetor, J.I. (1999) Lead-Poisoning in Two Distant States of Nigeria: An Indication of the Real Size of the Problem. African Journal of Medicine and Medical Sciences, 28, 107-112.

[38] Babalola, O.O. and Babajide, S.O. (2009) Selected Heavy Metals and Electrolyte Levels in Blood of Workers and Residents of Industrial Communities. African Journal of Biochemistry Research, 3, 37-40.

[39] Hassan, M.M., Nuhu, A.A., Sallau, M.S., Majiya, H.M. and Mohammed, A.K. (2015) Zamfara Lead Poisoning Saga: Comparison of Lead Contamination Level of Water Samples and Lead Poisoning in Bagega Artisanal Gold Mining District, Nigeria. Journal of Chemical and Pharmaceutical Research, 7, 7-12.

[40] Joint UNEP/OCHA Environment Unit (2010) Lead Pollution and Poisoning Crisis Environmental Emergency Response Mission Zamfara State, Nigeria September/ October.

https://www.unocha.org/sites/unocha/files/Lead\%20Pollution\%20and\%20Poisoning \%20Crisis\%20Environmental\%20Emergency\%20Response\%20Mission\%20Zamfara \%20State\%20Nigeria\%202010.pdf

[41] Adebamowo, E.O., Agbede, O.A., Sridhar, M.K.C. and Adebamowo, C.A. (2006) An Examination of Knowledge, Attitudes and Practices Related to Lead Exposure in South Western Nigeria. BMC Public Health, 6, 82.

https://doi.org/10.1186/1471-2458-6-82

[42] Agaba, E.I., Agaba, P.A. and Wigwe, C.M. (2004) Use and Abuse of Analgesics in Nigeria: A Community Survey. Nigerian Journal of Medicine, 13, 379-382.

[43] World Health Organization (WHO) (2005) WHO Steps Instrument: Section 4: Guide to Physical Measurements.

https://www.who.int/ncds/surveillance/steps/Section\%204\%20Step\%202\%20Physica 1\%20Measurements.pdf

[44] Graziano, J.H. (1994) Validity of Lead Exposure Markers in Diagnosis and Surveillance. Clinical Chemistry, 40, 1387-1390.

[45] Adeloye, D., Basquill, C., Aderemi, A.V., Thompson, J.Y. and Obi, F.A. (2015) An Estimate of the Prevalence of Hypertension in Nigeria: A Systematic Review and Meta-Analysis. Journal of Hypertension, 33, 230-242.

https://doi.org/10.1097/HJH.0000000000000413

[46] Akinlua, J.T., Meakin, R., Umar, A.M. and Freemantle, N. (2015) Current Prevalence Pattern of Hypertension in Nigeria: A Systematic Review. PLoS ONE, 10, e0140021. https://doi.org/10.1371/journal.pone.0140021 
[47] Anetor, J.I. (2002) Serum Uric Acid and Standardized Urinary Protein: Reliable Bio-Indicators of Lead Nephropathy in Nigerian Lead Workers. African Journal of Biomedical Research, 5, 19-24.

[48] Babalola, O.O., Ojo, L.O. and Aderemi, M.O. (2005) Lead Levels in Some Biological Samples of Automechanics in Abeokuta Nigeria. Indian Journal of Biochemistry and Biophysics, 42, 401-403.

[49] Jung, K.-Y., Lee, S.-J., Kim, J.-Y., Hong, Y.-S., Kim, S.-R., Kim, D. and Song, J.-B. (1998) Renal Dysfunction Indicators in Lead Exposed Workers. Journal of Occupational Health, 40, 103-109. https://doi.org/10.1539/joh.40.103

[50] Pergande, M., Jung, K., Precht, S., Fels, L.M., Herbort, C. and Stolte, H. (1994) Changed Excretion of Urinary Proteins and Enzymes by Chronic Exposure to Lead. Nephrology Dialysis Transplantation, 9, 613-618. https://doi.org/10.1093/ndt/9.6.613

[51] Batuman, V., Dreisbach, A., Chun, E. and Naumoff, M. (1989) Lead Increases the Red Cell Sodium-Lithium Counter Transport. American Journal of Kidney Diseases, 14, 200-203. https://doi.org/10.1016/S0272-6386(89)80071-X

[52] Weiler, E., Khalil-Manesh, F. and Gonick, H. (1988) Effects of Lead and Natriuretic Hormone on Kinetics of Sodium-Potassium-Activated Adenosine Triphosphatase: Possible Relevance to Hypertension. Environmental Health, Perspectives, 78, 113-118. https://doi.org/10.1289/ehp.8878113

[53] Moreau, T., Hannaert, P., Orssaud, G., Huel, G., Garay, R.P., Claude, J.R., Juguet, B., Festy, B. and Lellouch, J. (1988) Influence of Membrane Sodium Transport upon the Relation between Blood Lead and Blood Pressure in a General Male Population. Environmental Health, Perspective, 78, 47-51. https://doi.org/10.1289/ehp.887847

[54] Khalil-Manesh, F. (1993) Lead Induced Hypertension: Possible Role of Endothelial Factors. American Journal of Hypertension, 6, 723-729. https://doi.org/10.1093/ajh/6.9.723

[55] Gonick, H.C., Ding, Y., Bondy, S., Ni, Z. and Vaziri, N.D. (1997) Lead-Induced Hypertension: Interplay of Nitric Oxide and Reactive Oxygen Species. Hypertension, 30, 1487-1492. https://doi.org/10.1161/01.HYP.30.6.1487

[56] Vaziri, N.D., Liang, K. and Ding, Y. (1999) Increased Nitric Oxide Inactivation by Reactive Oxygen Species in Lead-Induced Hypertension. Kidney International, 56, 1492-1498. https://doi.org/10.1046/j.1523-1755.1999.00670.x

[57] Boscolo, P. and Carmignani, M. (1988) Nuerohumoral Blood Pressure Regulation in Lead Exposure. Environmental Health, Perspective, 78, 101-106. https://doi.org/10.1289/ehp.8878101

[58] Vander, A.J. (1988) Chronic Effects of Lead on the Renin-Angiotensin System. Environmental Health Perspectives, 78, 77-83. https://doi.org/10.1289/ehp.887877

[59] Chai, S. and Webb, R.C. (1988) Effects of Lead on Vascular Reactivity. Environmental Health, Perspective, 78, 85-89. https://doi.org/10.1289/ehp.887885

[60] Craig, L.S., Gage, A.J. and Thomas, A.M. (2018) Prevalence and Predictors of Hypertension in Namibia: A National-Level Cross-Sectional Study. PLoS ONE, 13, e0204344. https://doi.org/10.1371/journal.pone.0204344

[61] Saeed, A.A. and Al-Hamdan, N.A. (2013) Anthropometric Risk Factors and Predictors of Hypertension among Saudi Adult Population-A National Survey. Journal of Epidemiology and Global Health, 3, 197-204. https://doi.org/10.1016/j.jegh.2013.08.004

[62] United Nations Environment Programme (2018) Lead Petrol Phase out-Global Sta- 
tus July 2018.

https://wedocs.unep.org/bitstream/handle/20.500.11822/25422/MapWorldLead_Ma rch2018.pdf? sequence $=1$ \&isAllowed $=y$

[63] Apanpa-Qasim, A.F.I., Adeyi, A.A., Mudliar, S.N., Raghunathan, K. and Thawale, P. (2016) Examination of Lead and Cadmium in Water-Based Paints Marketed in Nigeria. Journal of Health and Pollution, 6, 43-49. https://doi.org/10.5696/2156-9614-6.12.43

[64] Adogame, L., Fabunmi, V. and Osa-Egharevba, F. (2017) Lead in Solvent-Based Paints for Home Use in Nigeria (July). Sustainable Research and Action for Environmental Development (SRADev Nigeria), 1-39.

https://ipen.org/sites/default/files/documents/ipen-nigeria-lead-report-v1_1-en.pdf

[65] Finkcleman, J. (1996) Phasing out Leaded Gasoline Will Not End Lead Poisoning in Developing Countries. Environmental Health, Perspectives, 104, 1-2.

https://doi.org/10.2307/3432745

[66] Ogunseitan, O.A. and Smith, T.R. (2007) The Cost of Environmental Lead (Pb) Poisoning in Nigeria. African Journal of Environmental Science and Technology, 1, 27-36. 